\title{
Pengaruh Moderasi Opini Audit terhadap Persistensi Laba
}

\author{
Bene dicta Anggit Sekartaji, Ghizella Nada Elvina \\ Titin Pranoto, Yang Elvi Ade lina* \\ Program Studi Akuntansi, Sekolah Bisnis dan Ekonomi Universitas Prasetiya Mulya \\ BSD City Kavling Edutown I.1 , Jl. BSD Raya Utama, BSD City, Tangerang 15339
}

Keywords:

Earnings Quality, Audit

Opinion, Earnings

Persistence

\section{Kata Kunci:}

Kualitas Laba, Opini

Audit, Persistensi Laba

\section{*Corresponding author:}

yang.elvi@pmbs.ac.id

\begin{abstract}
This research aims to analyze the effect of last year earnings to current earnings which moderated by audit opinion from listed companies on Indonesia Stock Exchange from 2011-2017. Total sample of this research are from 288 companies, which consist of 2.016 samples, including all of industries except financial industries chosen by purposive sampling method. Model of data analysis for this research uses Driscoll-Kraay method in pooled least square model.The result of this research found that last year earnings have positive significant effect on current earnings. The effect was describe as earnings persistence. Moreover, this research also indicates the effect of last year earnings on current earnings is moderated by audit opinion. Which modified audit opinion is proven to weakens the earnings persistence. The sensitivity test also showed that qualified and disclaimer opinion are proven to weaken earnings persistence. This research uses only one model to measure the earnings persistence. The result on qualified and disclaimer audit opinion is not representative due to less total sample on both audit opinion. Researchers expecting that this research can give a new comprehension for management about earnings persistence and audit opinion, and also can help investor for taking a decision on investment.
\end{abstract}

\section{Sari Pati}

Penelitian ini bertujuan untuk menganalisis pengaruh laba tahun lalu terhadap laba tahun berjalan yang dimoderasi oleh opini audit pada perusahaan yang terdaftar di Bursa Efek Indonesia tahun 2011-2017. Total sampel penelitian berasal dari 288 perusahaan yang terdiri dari 2.016 sampel, mencakup semua industri kecuali keuangan dan dipilih menggunakan metode purposive sampling. Penelitian menggunakan metode Driscoll-Kraay pada model pooled least square. Hasil dari penelitian menemukan bahwa laba tahun lalu memiliki pengaruh positif signifikan terhadap laba tahun berjalan. Pengaruh tersebut dijelaskan sebagai persistensi laba. Selain itu, opini audit terbukti dapat me moderasi pengaruh laba tahun lalu terhadap laba tahun berjalan. Dimana opini modifikasian terbukti dapat memperlemah persistensi laba. Hasil uji sensitivitas juga menunjukan bahwa opini audit qualified dan disclaimer terbukti dapat memperlemah persistensi laba. Penelitian ini menggunakan satu model pengukuran persistensi laba. Hasil uji pada opini qualified dan disclaimer dianggap kurang representatif karena sedikitnya jumlah observasi untuk kedua jenis opini tersebut. Diharapkan penelitian dapat memberikan pemahaman baru bagi manajemen terkait persistensi laba dan opini audit, dan dapat membantu investor dalam menentukan keputusan investasi. 


\section{Pendahuluan}

Dalam menjalankan kegiatan guna menjaga kelangsungan usahanya, setiap perusahaan akan membuat perencanaan keuangan dan operasionalnya masing-masing. Seluruh hasil perencanaan termasuk perkembangan keuangan dan kegiatan operasional perusahaan tersebut terdapat dalam laporan keuangan. Salah satu informasi dalam laporan keuangan yang menjadi acuan utama investor dan kreditor sebagai pemangku kepentingan dalam pengambilan keputusan pembuatan kontrak, investasi dan pembuatan standar adalah laba akuntansi (Schipper \& Vincent, 2003).

Pemangku kepentingan hingga saat ini memandang laba akuntansi sebagai informasi terbaik dalam menilai kinerja perusahaan dan digunakan untuk memprediksi kemampuan laba di masa depan karena dapat digunakan untuk menilai efisiensi perusahaan dalam menggunakan sumber daya ekonominya (Yocelyn \& Christiawan, 2012). Informasi laba yang dapat diandalkan dan dapat digunakan untuk mengurangi risiko kesalahan dalam pengambilan keputusan merupakan laba yang berkualitas (Dechow, Ge \& Schrand, 2010; Schipper \& Vincent, 2003). Laba yang berkualitas merupakan laba yang dapat mencerminkan laba yang berkesinambungan atau laba yang bersifat kontinu di masa depan yang ditentukan oleh komponen kas dan akrual yang dapat menjadi cerminan kinerja keuangan perusahaan yang sesungguhnya (Penman, 2001). Sujana, Yasa dan Badera (2017), menyatakan bahwa perusahaan yang memiliki laba yang berkesinambungan atau yang bersifat kontinu tiap tahunnya dalam periode tertentu merupakan perusahaan dengan laba yang persisten.

Menurut Subramanyam dan Wild (1996), analisis keuangan yang baik dapat mengenali komponen laba yang stabil dan dapat diprediksi atau komponen yang mampu bertahan (persisten). Komponen laba yang persisten memisahkan komponen pendapatan dan beban antara yang permanen atau berulang (recurring) dan yang tidak permanen atau tidak berulang (nonrecurring), sehingga dapat memberikan penilaian mengenai kontinuitas laba yang dapat dipercaya. Oleh karena itu, perlu dilihat apakah cara pengakuan pendapatan dan beban yang diterapkan perusahaan sudah sesuai dengan standar akuntansi yang berlaku dan penyajian laporan keuangan sudah sesuai dengan konsep dasar penyusunan laporan keuangan, yaitu asumsi kelangsungan usaha (going concern). 
Kelangsungan usaha perusahaan tersebut dapat dinilai dari penyajian laporan keuangan sesuai dengan standar akuntansi yang berlaku serta hubungan antara laba tahun berjalan dan laba tahun sebelumnya yang dapat diandalkan sebagai penilaian dalam pengambilan keputusan.

Maka dibutuhkan auditor eksternal sebagai pihak ketiga yang independen dan profesional yang akan mengeluarkan opini berdasarkan hasil pemeriksaan apakah laporan keuangan sudah disajikan secara wajar sesuai dengan prinsip akuntansi yang berlaku umum (Fadjar \& Firdaus, 2009; Herusetya, 2012). Opini audit yang dikeluarkan auditor terdiri dari dua kelompok jenis yaitu opini audit unqualified atau nonmodifikasian dan opini audit modifikasian (modified) (Vichitsarawong \& Pornupatham, 2015). Dalam opini modifikasian, terdapat tiga jenis opini berdasarkan tingkatannya yaitu opini audit wajar dengan paragraf penjelas (unqualified with emphasis of matter/UEM), opini wajar dengan pengecualian (qualified) dan opini disclaimer, atau tidak memberikan pendapat.

Krissindiastuti dan Rasmini (2016) dan Rudyawan dan Badera (2009) dalam penelitiannya menemukan bahwa auditor mengeluarkan opini audit modifikasian saat menemukan masalah dalam perusahaan, salah satunya terkait kelangsungan usaha. Menurut Dechow et al., (2010), pemberian opini audit modifikasian tersebut menandakan bahwa terdapat masalah dalam perusahaan sehingga laba yang disajikan tidak berkualitas karena laba tidak menggambarkan keadaan perusahaan yang sesungguhnya. Maka dengan adanya informasi mengenai kondisi perusahaan dari pihak independen tersebut, opini audit dapat dijadikan sebagai indikator yang dapat menggambarkan persistensi laba perusahaan yang tercermin lewat hubungan antara laba tahun sebelumnya dan laba tahun berjalan. Sehingga, opini audit dapat menjadi informasi yang dapat digunakan pemangku kepentingan dalam mempertimbangkan pengambilan keputusan (Indriani \& Ratmono, 2015).

Penelitian ini dilakukan untuk menganalis is pengaruh laba tahun sebelumnya terhadap laba tahun berjalan yang menggambarkan persistensi laba, serta menganalisis pengaruh opini audit terhadap persistensi laba dengan menggunakan opini audit sebagai pemoderasi pengaruh laba tahun sebelumnya terhadap laba tahun berjalan. Penelitian mengenai opini audit dan persistensi laba telah dilakukan sebelumnya oleh Vichitsarawong dan Pornupatham (2015) yang menemukan bahwa opini 
audit sebagai variabel moderasi dapat memoderasi persistensi laba dan penelitian oleh Moghaddam, Monavar, Mostafaei, Ghased \& Kakhi (2016) yang menemukan perbedaan hasil, yaitu opini audit tidak memoderasi persistensi laba.

Penelitian ini merupakan replikasi dari penelitian sebelumnya yang dilakukan Vichitsarawong dan Pornupatham (2015), untuk menganalisis dan menguji data empiris pada perusahaan-perusahaan yang sahamnya terdaftar dan aktif diperdagangkan di Bursa Efek Indonesia (BEI), yang bergerak di seluruh bidang industri kecuali industri keuangan. Penelitian ini berkontribusi pada literatur terdahulu terkait opini audit dan persistensi laba. Variabel-variabel yang digunakan dalam penelitian ini adalah laba tahun berjalan sebagai variabel terikat, laba tahun sebelumnya sebagai variabel bebas, serta jenis opini audit sebagai variabel moderasi. Hasil penelitian ini bertujuan menganalisis pengaruh moderasi opini audit terhadap persistensi laba.

Sistematika penelitian ini terdiri dari lima bagian. Bagian pertama berisi latar belakang penelitian. Bagian kedua memaparkan konsep dasar, tinjauan literatur, pengembangan hipotesis penelitian dan kerangka penelitian. Bagian ketiga merupakan penjabaran metode penelitian dan model penelitian yang digunakan. Kemudian bagian keempat berisi analisis pembahasan dari hasil olah data berdasarkan model penelitian dan tinjauan literatur. Sedangkan bagian kelima membahas ikhtisar dari hasil analisis pembahasan, keterbatasan hasil penelitian berdasarkan hasil penelitian, saran untuk perbaikan penelitian ke depan dan implikasi hasil pene litian

\section{Telaah Literatur dan Pengembangan Hipotesis}

Menurut Jensen dan Meckling (1976), dalam menjalankan kegiatan usaha suatu perusahaan, principal sebagai pemilik akan memberikan wewenang dalam mengendalikan kegiatan operasional perusahaan kepada agen (manajemen) dengan mengelola dan mengendalikan perusahaan dengan menggunakan sumber daya ekonomi perusahaan tersebut. Agen akan menyajikan laporan keuangan kepada principal terkait hasil kinerja dan kondisi perusahaan dalam satu periode. Laporan keuangana berisi hasil proses akuntansi yang dapat digunakan sebagai alat komunikasi data keuangan atau aktivitas suatu perusahaan dengan pihak-pihak pemangku kepentingan (Munawir, 2007). Salah satu 


\section{saki}

informasi dalam laporan keuangan yang digunakan untuk pengambilan keputusan adalah laba, karena dapat menggambarkan kegiatan operasional perusahaan. Dengan demikian laba harus berkualitas atau bersifat relevan, yaitu dapat menggambarkan keadaan perusahaan yang sebenarnya, sehingga dapat berguna sebagai dasar dalam pengambilan keputusan yang tepat (Cohen, 2003) dan (Dechow, Ge, dan Schrand, 2010). Subramanyam dan Wild (1996) menyatakan bahwa laba yang berkualitas adalah laba yang mampu bertahan (persisten) karena laba tersebut dari tahun ke tahun stabil dan dapat diprediksi karena sebagian besar bagian laba menggambarkan pendapatan dan beban yang berulang (recurring).

Pemilik membutuhkan pihak ketiga yang independen dan profesional yaitu auditor yang bertujuan untuk menilai kewajaran laporan keuangan yang telah disajikan oleh manajemen. Auditor akan memeriksa bukti atas informasi dalam laporan keuangan yang bertujuan untuk menentukan apakah laporan keuangan sudah tersaji sesuai dengan asersi yang telah ditentukan, yaitu keberadaan (occurence) atau keterjadian (existence), kelengkapan (completeness), hak dan kewajiban (rights and obligations), penilaian (valuation), penyajian dan pengungkapan (presentation and disclosure) (Arens, Elder, Beasley, \& Hogan, 2012). Nantinya, auditor akan mengeluarkan opini atau pendapat atas kewajaran laporan keuangan sebagai hasil dari pemeriksaan yang telah dilakukan pada laporan keuangan perusahaan (Tobing \& Nirwana, 2004).

Penelitian yang dilakukan oleh Vichitsarowong dan Pornupatham (2015) dan Moghaddam et al. (2016) menganalisis apakah terdapat faktor yang dapat mempengaruhi persistensi laba yang digambarkan dengan pengaruh laba tahun lalu terhadap laba tahun sebelumnya. Faktor tersebut yaitu opini audit, karena opini audit dapat menggambarkan keadaan perusahaan yang sebenarnya. Opini audit tertentu akan memperkuat atau memperlemah persistensi laba.

Mengacu pada Vichitsarawong dan Pornupatham (2015), opini audit terbagi menjadi 2 kelompok jenis yaitu jenis nonmodifikasian dan modifikasian. Opini audit non modifikasian atau opini audit wajar tanpa pengecualian (unqualified) diberikan pada saat auditor menilai bahwa laporan keuangan perusahaan sudah disajikan sesuai dengan standar dan prinsip akuntansi, dalam semua aspek yang bersifat material (Julianto, 2010). 
Sedangkan opini audit modifikasian terbagi atas tiga jenis yaitu wajar tanpa pengecualian dengan paragraf penjelas, yang diberikan jika laporan keuangan sudah disajikan secara wajar namun auditor perlu menambahkan penekanan pada suatu hal yang dijelaskan dalam bentuk paragraf. Opini audit modifikasian selanjutnya adalah wajar dengan pengecualian (qualified), yang diberikan jika auditor sudah menemukan bukti yang cukup dan tepat tetapi terdapat kesalahan penyajian yang material namun tidak pervasif, atau auditor menyimpulkan terdapat kemungkinan dampak kesalahan penyajian yang bersifat material namun tidak pervasif. Jenis opini modifikasian terakhir adalah opini tidak menyatakan pendapat (disclaimer) yang diberikan jika auditor menyimpulkan terdapat kesalahan penyajian yang bersifat material dan pervasif, selain itu terdapat ketidakpastian yang bersifat pervasif (SA 705).

\section{Pengembangan Hipotesis}

Dalam pengambilan keputusan investasi, investor akan mengacu pada laporan keuangan sebagai sarana untuk mengetahui kinerja dan kondisi keuangan perusahaan. Salah satu komponen dari laporan keuangan adalah laba akuntansi, yang menjadi salah satu faktor penilaian utama investor dalam menentukan keputusan berinvestasi (Hariyati, 2014). Selain melihat besaran laba perusahaan, investor perlu mengetahui bagaimana kualitas laba yang disajikan oleh perusahaan. Laba yang berkualitas adalah laba yang dapat mencerminkan keadaan perusahaan yang sebenarnya dan dapat menjadi dasar dalam menilai atau memprediksi kemampuan perusahaan dalam memperoleh laba pada tahun selanjutnya (Bellovary, Akers \& Diacomino, 2005). Hal ini sejalan dengan kualitas laba menurut Statement of Financial Accounting Concept No. 2 yang menjelaskan bahwa salah satu karakteristik laba adalah relevan. Relevan dapat diartikan sebagai laba yang memiliki nilai prediksi, sehingga laba tersebut dapat menjadi dasar perhitungan dalam memprediksi laba tahun selanjutnya (Surifah, 2010).

Penman (2001) menjelaskan bahwa laba yang berkualitas adalah laba yang bersifat kontinu atau berulang. Laba yang bersifat kontinu tersebut merupakan laba yang persisten. Menurut Imroatussolihah (2013), persistensi laba diartikan sebagai kemampuan laba tahun sebelumnya yang 
dapat mencerminkan laba periode berjalan karena menggambarkan keadaan perusahaan yang sebenarnya. Penelitian tersebut didukung oleh penelitian Budiyasa dan Sisdyani (2015) dan Belkaoui (1993) yang menjelaskan bahwa laba yang persisten adalah laba tahun sebelumnya yang dapat menjadi gambaran untuk menganalisa atau memprediksi kemampuan perusahaan dalam menciptakan laba periode berjalan.

Sehingga dalam melakukan pengukuran persistensi laba, terdapat pengaruh laporan keuangan tahun sebelumnya yang menjadi dasar dalam perhitungan prediksi laba tahun berjalan. Jika laba pada tahun sebelumnya berkualitas rendah, maka laba tersebut tidak menggambarkan keadaan perusahaan yang sebenarnya dan akan berdampak pada perhitungan prediksi laba tahun berjalan kurang tepat. Hal tersebut menunjukkan laba yang tidak persisten (Vichitsarawong \& Pornupatham, 2015). Sebaliknya, jika laba pada tahun sebelumnya berkualitas baik karena menggambarkan keadaan perusahaan yang sebenarnya maka prediksi laba tahun berjalan akan tepat. Sehingga mengacu pada penelitian terdahulu, dapat dirumuskan hipotes is sebagai berikut :

\section{H1. Laba tahun lalu berpengaruh terhadap laba tahun berjalan.}

Komponen laba yang persisten memisahkan komponen pendapatan dan beban antara yang permanen atau berulang (recurring) dan yang tidak permanen atau tidak berulang (nonrecurring), sehingga dapat memberikan penilaian mengenai kelanjutan laba yang dapat dipercaya. Membedakan pendapatan dan beban tersebut tergantung pada kegiatan operasional perusahaan pada umumnya, sehingga perlu diketahui kapan perusahaan mengakui pendapatan dan bebannya. Oleh karena itu, perlu dilihat apakah cara pengakuan pendapatan dan beban yang diterapkan perusahaan sudah sesuai dengan standar akuntansi yang berlaku dan apakah penyajiannya sudah sesuai dengan asumsi dasar penyusunan laporan keuangan, yaitu kelangsungan usaha (going concern). Sehingga dibutuhkan auditor eksternal sebagai pihak ketiga yang independen dan profesional untuk memeriksa apakah laporan keuangan sudah disajikan secara wajar sesuai dengan prins ip akuntansi yang berlaku umum (Fadjar \& Firdaus, 2009; Herusetya, 2012). 
Auditor akan mengeluarkan opini audit sebagai hasil dari proses audit yang telah dilakukan yang menunjukkan tingkat kewajaran laporan keuangan perusahaan (Tobing \& Nirwana, 2004). Opini audit berperan penting bagi pengguna laporan keuangan, seperti investor, kreditor, dan para pemegang saham perusahaan karena dapat memberikan keyakinan bagi para pengguna laporan keuangan apakah informasi yang disajikan dalam laporan keuangan sudah sesuai dengan keadaan perusahaan yang sebenarnya dan standar akuntansi yang berlaku (Osesoga dan Ardianto, 2011). Opini audit yang dikeluarkan terbagi dalam dua jenis yaitu opini nonmodifikasian dan opini modifikasian. Opini nomodifikasian (unqualified) merupakan opini yang menjukkan bahwa perusahaan telah bebas dari salah saji yang material dan mengindikasikan kualitas laba perusahaan baik karena sudah disajikan secara wajar sesuai dengan standar akuntansi yang berlaku (Soewiyanto, 2012). Kualitas laba yang baik merupakan sebuah indikator bahwa laba yang disajikan persisten (Vidayanti, Vestasari \& Farisa, 2014). Sedangkan opini modifikasian merupakan opini yang dimodifikasi karena adanya penjelasan tambahan, penurunan kinerja operasional ataupun salah saji yang bersifat material yang membuat auditor meragukan kemampuan perusahaan dalam menjaga kelangsungan usahanya (Haron, Hartadi, Ansari \& Ismail, 2009). Keadaan ini mengindikasikan adanya masalah dalam perusahaan yang akan menunjukkan kualitas laba yang cenderung rendah. Dengan demikian hal ini memberikan efek negatif terhadap persistensi laba perusahaan.

Opini audit modifikasian terbagi dalam tiga jenis opini, yaitu opini UEM, opini qualified dan opini disclaimer. Vichitsarowong dan Pornupatham (2015) dalam penelitiannya menemukan bahwa terdapat perbedaan tingkat persistensi laba antara perusahaan-perusahaan yang memiliki opini audit modifikasian. Perusahaan yang menerima opini audit UEM memiliki laba yang lebih persisten dibandingkan perusahaan yang menerima opini audit wajar dengan pengecualian (qualified) dan tidak memberikan opini (disclaimer) karena opini audit tersebut menggambarkan bahwa perusahaan yang mendapatkan opini audit UEM sebenarnya sudah menyajikan laporan keuangan secara wajar namun ada tambahan penjelas dari auditor atas penyajian laporan keuangannya. Pemberian opini audit qualified dan disclaimer, juga akan berpengaruh terhadap persistensi laba perusahaan. Perusahaan 
yang mendapatkan opini qualified menunjukkan bahwa perusahaan memiliki masalah-masalah seperti penurunan kinerja operasional ataupun salah saji yang bersifat material sehingga auditor menyatakan pengecualian dalam penyajian laporan keuangan. Sedangkan pada opini audit disclaimer, auditor tidak memiliki bukti yang cukup baginya sehingga merasa ruang lingkupnya dibatasi. Maka keadaan ini membuat auditor tidak dapat memberikan pendapat atas laporan keuangan.

Dengan pemberian jenis-jenis opini modifikasian tersebut, maka seorang investor dalam menggunakan laporan keuangan untuk pengambilan keputusan akan meragukan kemampuan perusahaan karena tidak dapat memperkirakan dengan tepat keadaan perusahaan pada tahun setelahnya. Maka dalam penelitian ini, opini audit mampu memoderasi pengaruh laba tahun sebelumnya terhadap laba tahun berjalan yang menggambarkan persistensi laba. Atas dasar tersebut, maka penelitian ini akan menganalisis apakah opini audit dapat memoderasi pengaruh antara laba tahun sebelumnya terhadap laba tahun berjalan dengan rumusan hipotesis sebagai berikut:

\section{H2. Jenis opini audit memoderasi pengaruh laba tahun lalu terhadap laba tahun berjalan.}

\section{Kerangka Pemikiran}

\section{Gambar 1. Ke rangka Pemikiran}

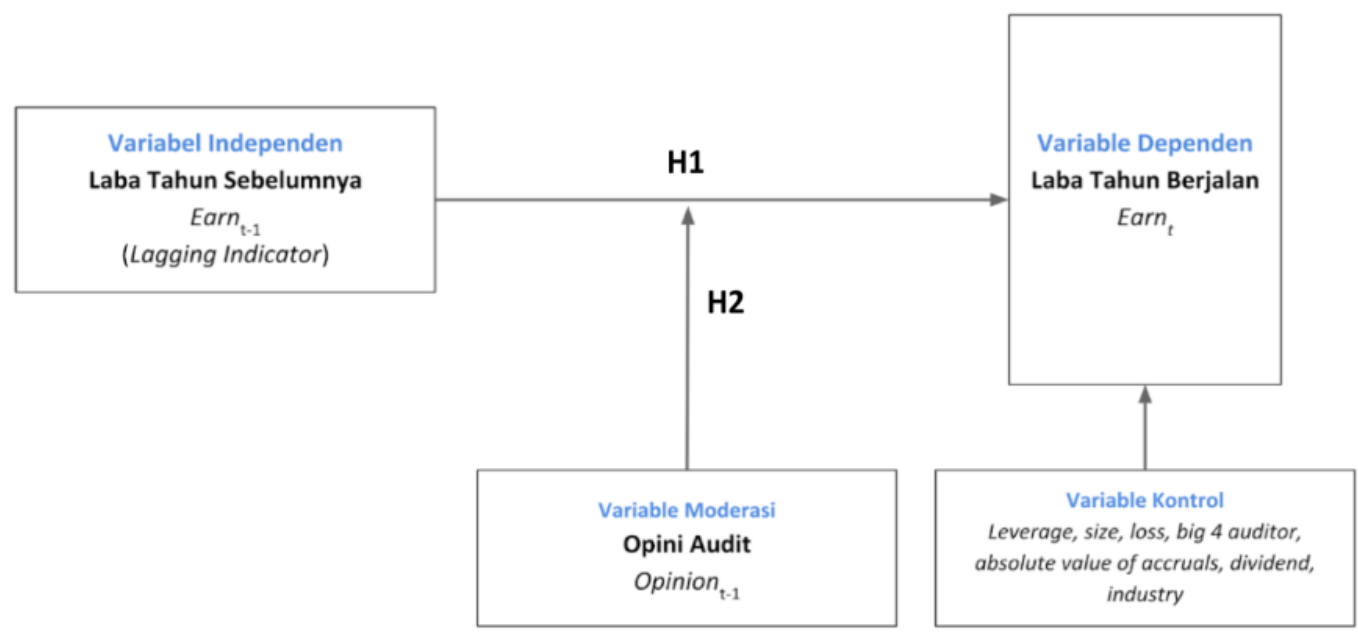

\section{Metode Penelitian}




\section{Populasi dan Sampel}

Sampel penelitian menggunakan perusahaan pada setiap industri kecuali keuangan, yang terdaftar dan sahamnya aktif diperdagangkan di Bursa Efek Indonesia dari tahun 2011-2017. Jenis data yang digunakan dalam penelitian adalah data sekunder, yang didapatkan dari S\&P Capital IQ dan situs resmi Bursa Efek Indonesia. Penelitian ini mengeliminasi perusahaan yang laporan keuangan auditnya tidak lengkap terhitung pada periode tahun 2011-2017. Pengumpulan data pada penelitian ini menggunakan metode purposive sampling yang mendapatkan total sampel sebanyak 2,016 terdiri dari 1,091 opini wajar tanpa paragraf penjelas dan 925 opini modifikasian yang berasal dari 288 perusahaan.

Tabel 1. Perolehan Sampel Pene litian

\begin{tabular}{|c|c|c|}
\hline Krite ria & Perusahaan & Observasi \\
\hline Perusahaan yang tercatat di Bursa Efek Indonesia & 583 & 4.081 \\
\hline $\begin{array}{l}\text { Dikurang: Perusahaan yang tercatat di Bursa Efek } \\
\text { Indones ia setelah tahun } 2009\end{array}$ & $(229)$ & $(1.063)$ \\
\hline Dikurang: Perusahaan yang bergerak di industri keuangan & (64) & $(448)$ \\
\hline Dikurang: Perusahaan yang datanya tidak lengkap & (2) & (14) \\
\hline Sampel Final & 288 & 2.016 \\
\hline
\end{tabular}

(Sumber: Data diolah)

\section{Ope rasionalisasi Variabel}

Variabel dependen pada penelitian ini adalah laba tahun sebelumnya $\left(\mathrm{EARN}_{\mathrm{t}-1}\right)$ yang diukur menggunakan model yang mengacu pada Sloan (1996) yaitu membagi pendapatan operasional tahun sebelumnya dengan rata-rata total aset tahun sebelumnya. Variabel independen adalah laba tahun berjalan $\left(\mathrm{EARN}_{\mathrm{t}}\right)$ yang merupakan hasil pembagian antara pendapatan operasional tahun berjalan dengan rata-rata total aset tahun berjalan. Penelitian juga menggunakan variabel moderasi yaitu opini audit (OPINION) diukur menggunakan dummy yang bernilai satu jika perusahaan menerima opini audit unqualified with emphasis of matter, qualified, dan disclaimer serta bernilai nol jika selain dari yang telah disebutkan. 
Variabel kontrol pada penelitian ini akan mengacu pada penelitian terdahulu yang dilakukan oleh Vichitsarawong dan Pornupatham (2015) mengenai pengaruh opini audit terhadap persistensi laba. Variabel kontrol yang digunakan yaitu Leverage $\left(\operatorname{LEV}_{\mathrm{it}-1}\right)$, Ukuran Perusahaan $\left(\mathrm{SIZE}_{\mathrm{it}-1}\right)$, Kerugian $\left(\operatorname{LOSS}_{\mathrm{it}-1}\right)$, Auditor KAP Big $4\left(\mathrm{AUDITOR}_{\mathrm{it}-1}\right)$, Absolut Akrual (ABS_ACC $\left.\mathrm{it}_{\mathrm{t}-1}\right)$, Dividen $\left(\mathrm{DIV}_{\mathrm{it}-1}\right)$, dan Industri.

Tabel 2. Ope rasionalisasi Variabel Pene litian

\begin{tabular}{|c|c|c|}
\hline Variabel & Proksi & Rumus \\
\hline \multirow[t]{4}{*}{ Laba (EARN) } & Laba tahun sebelumnya $\left(\mathrm{EARN}_{\mathrm{t}-1}\right)$ & Operating Income $_{(\mathrm{t}-1)}$ \\
\hline & (Lag Indicator) & Average Total Asset $_{(\mathrm{t}-1)}$ \\
\hline & Laba tahun berjalan $\left(\mathrm{EARN}_{\mathrm{t}}\right)$ & Operating Income $_{(\mathrm{t})}$ \\
\hline & & Average Total Asset $_{(\mathrm{t})}$ \\
\hline $\begin{array}{l}\text { Opini Audit } \\
\left(\text { OPINION }_{\mathrm{it}-1}\right)\end{array}$ & $\begin{array}{c}\text { Variabel Dummy } \\
0=\text { Opini audit nonmodifikasian } \\
1=\text { Opini audit modifikasian }\end{array}$ & \\
\hline Leverage $\left(\mathrm{LEV}_{\mathrm{it}-1}\right)$ & Debt to Asset & Total Debt \\
\hline & & Total Assets \\
\hline $\begin{array}{l}\text { Ukuran Perusahaan } \\
\qquad\left(\mathrm{SIZE}_{\mathrm{it}-1}\right)\end{array}$ & Total Aset & $\begin{array}{c}\text { Logaritma Natural Total } \\
\text { Aset }\end{array}$ \\
\hline Kerugian $\left(\mathrm{LOSS}_{\mathrm{it}-1}\right)$ & $\begin{array}{c}\text { Variabel Dummy } \\
0=\text { Tidak menga lami kerugian } \\
1=\text { Mengalami kerugian }\end{array}$ & \\
\hline $\begin{array}{l}\text { Auditor KAP Big } 4 \\
\quad\left(\text { AUDITOR }_{\mathrm{it}-1}\right)\end{array}$ & $\begin{array}{c}\text { Variabel Dummy; } \\
0=\text { Bukan auditor KAP Big } 4 \\
1=\text { Auditor KAP Big } 4\end{array}$ & \\
\hline $\begin{array}{l}\text { Absolut Akrual } \\
\left(\mathrm{ABS} \_\mathrm{ACC}_{\mathrm{it}-1}\right)\end{array}$ & Akrual & $\frac{\text { Net Income }- \text { Operating Cash F llow }}{\text { Average Total Asset }}$ \\
\hline Dividen $\left(\mathrm{DIV}_{\mathrm{it}-1}\right)$ & $\begin{array}{c}\text { Variabel Dummy; } \\
0=\text { Tidak membayar dividen } \\
1=\text { Membayar dividen }\end{array}$ & \\
\hline Industri (INDUSTRY) & $\begin{array}{c}\text { Variabel Dummy; } \\
0=\text { Indikator industri la innya } \\
1=\text { Indikator industri }\end{array}$ & \\
\hline
\end{tabular}




\section{Metode Analisis Data}

Penelitian melalui lima tahap metode analisis. Metode yang pertama adalah uji statistik deskriptif yang dilakukan untuk mengetahui karakteristik sampel dan menggambarkan variabelvariabel yang digunakan da lam penelitian, meliputi jumlah, sampel, nilai minimum, nilai maksimum, nilai rata-rata, dan standar deviasi (Gujarati, 2003). Metode yang kedua adalah uji ketepatan model, dengan melakukan uji regresi yang terdiri dari chow test, hausman test, dan lagrange multiplier test. Metode yang ketiga adalah melakukan uji asumsi klasik yang terdiri uji normalitas, uji multikolinearitas, uji heteroskedastisitas, dan uji autokorelasi. Metode keempat adalah melakukan uji hipotesis yang terdiri dari uji koefisien determinasi $\left(\mathrm{R}^{2}\right)$, uji signifikan parameter individual (uji statistik t), dan uji signifikansi simultan (uji statistik-F).

\section{Model Penelitian}

Penelitian ini mengadopsi model yang dikemukakan oleh Vichitsarawong dan Pornupatham (2015) untuk menguji pengaruh laba tahun lalu terhadap laba tahun berjalan yang menggambarkan persistensi laba, serta untuk menguji pengaruh opini audit sebagai variabel moderasi terhadap persistensi laba. Model penelitian yang digunakan adalah sebagai berikut:

$$
\begin{aligned}
\text { EARNT }_{i t}=\alpha+ & \beta_{1} \text { EARN }_{i t-1}+\beta_{2} \text { OPINION }_{i t-1}+\beta_{3} \text { EARN }_{i t-1} * \text { OPINION }_{i t-1}+\beta_{4} \text { LEV }_{i t-1} \\
& +\beta_{5} \text { SIZE }_{i t-1}+\beta_{6} \text { LOSS }_{i t-1}+\beta_{7} \text { AUDITOR }_{i t-1}+\beta_{8} \text { ABS }_{-} \text {ACC }_{i t-1}+\beta_{9} \text { IIV }_{i t-1} \\
& +\beta_{10} \text { INDUSTRY }+\varepsilon_{i t-1}
\end{aligned}
$$

Keterangan:
$E A R N_{i t}$
$=$ Laba operasional dibagi dengan rata-rata jumlah aset tahun $\mathrm{t}$
$E A R N_{i t-1}$
$=$ Laba operasional dibagi dengan rata-rata jumlah aset tahun $\mathrm{t}-1$
OPINION $_{\text {it-1 }}$
$=1$ jika auditor memberikan opini modif ikasian di tahun $\mathrm{t}-1$ dan 0 sebaliknya
$E A R N_{i t-1}$ XOPINION it-1 $_{1}=$ Interaksi antara opini audit modifikasian pada tahun $\mathrm{t}-1$ dan laba
$L E V_{i t-1}$ operasional dibagi dengan rata-rata jumlah aset pada tahun $\mathrm{t}-1$
$S I Z E_{i t-1}$ $=$ Total utang dibagi dengan total aset tahun $\mathrm{t}-1$
$\operatorname{LOSS}_{i t-1}$
= logaritma natural dari total aset tahun $\mathrm{t}-1$
AUDITOR it-1
$=1$ jika perusahaan mengalami kerugian pada tahun $\mathrm{t}-1$ dan 0 sebaliknya $=1 \mathrm{jika}$ perusahaan diaudit oleh auditor Big 4 pada tahun $\mathrm{t}-1$ dan 0 la innya 
$A B S \_A C C_{i t-1}$

$D I V_{i t-1}$

Fixed effect
= Nilai absolut akrual, yang ditentukan dengan menghitung laba bersih dikurangi arus kas pada tahun $\mathrm{t}-1$, yang dihitung dengan rata-rata total aset pada tahun $\mathrm{t}-1$

$=1$ jika perusahaan membayar dividen pada tahun $\mathrm{t}-1$ dan 0 sebaliknya

$=$ indikator industri dan tahun $\mathrm{t}-1$

\section{Analisis Regresi Moderasi}

Sehubungan dengan adanya variabel moderasi pada penelitian ini, maka digunakan metode analisis uji interaksi atau analis is regresi moderasi/moderated regression analysis (MRA). Uji interaksi merupakan uji dengan perkalian dua atau lebih variabel independen untuk melihat apakah terdapat faktor yang memperkuat atau memperlemah hubungan antara variabel bebas (variabel independen) dan variabel terikat (variabel dependen). Jika perkalian antara kedua variabel signifikan, maka terjadi moderasi dalam model penelitian. Menurut Zedeck (1971) dalam melakukan analisis regresi moderasi perlu dilakukan regresi pada tiga model penelitian, yaitu:

$$
\begin{aligned}
& Y=\alpha+\beta_{1} X+\varepsilon \\
& Y=\alpha+\beta_{1} X+\beta_{2} Z+\varepsilon \\
& Y=\alpha+\beta_{1} X+\beta_{2} Z+\beta_{3} X * Z+\varepsilon
\end{aligned}
$$

Menurut Sharma, Durand, dan Gur-Arie (1981) dan Sugiono (2004), variabel moderasi dapat diklasifikasikan ke dalam beberapa tipe yaitu, prediktor moderasi (predictor moderator), moderasi potensial (homologiser moderator), moderasi semu (quasi moderator), dan moderasi murni (pure moderator). Berikut ini merupakan tabel kriteria variabel moderasi menurut Sharma et al. (1981):

Tabe 1 3. Tabel Klasifikasi Variabel Mode rasi

\begin{tabular}{|l|c|c|}
\hline \multirow{2}{*}{ Jenis Mode rasi } & \multicolumn{2}{|c|}{ Krite ria } \\
\cline { 2 - 3 } & $\boldsymbol{\beta}_{\mathbf{2}}$ Pada persaman (2) & $\boldsymbol{\beta}_{\mathbf{3}}$ Pada persamaan (3) \\
\hline $\begin{array}{l}\text { Pre diktor Mode rasi (Predictor Moderasi) } \\
\text { Prediktor Moderasi merupakan variabel yang } \\
\text { hanya berperan sebagai variabel bebas } \\
\text { (independen) dalam sebuah model hubungan }\end{array}$ & $\begin{array}{c}\beta_{2} \neq 0 \\
\text { (Signifikan) }\end{array}$ & $\begin{array}{c}\beta_{3}=0 \\
\text { (Tidak Signifikan) }\end{array}$ \\
\hline $\begin{array}{l}\text { Mode rasi Potensial (Homologiser } \\
\text { Moderator) }\end{array}$ & $\begin{array}{c}\beta_{2}=0 \\
\text { (Tidak Signifikan) }\end{array}$ & $\begin{array}{c}\beta_{3}=0 \\
\text { (Tidak Signifikan) }\end{array}$ \\
\hline
\end{tabular}




\begin{tabular}{|c|c|c|}
\hline $\begin{array}{l}\text { Moderasi Potensial merupakan variabel yang } \\
\text { berpotensi menjadi variabel moderasi }\end{array}$ & & \\
\hline $\begin{array}{l}\text { Mode rasi Semu (Quasi Moderator) } \\
\text { Moderasi Semu merupakan variabel yang } \\
\text { memoderasi hubungan antara variabel bebas } \\
\text { (independen) dan variabel terikat (dependen), } \\
\text { yang juga sekaligus menjadi variabel bebas } \\
\text { (independen) }\end{array}$ & $\begin{array}{c}\beta_{2} \neq 0 \\
\text { (Signifikan) }\end{array}$ & $\begin{array}{c}\beta_{3} \neq 0 \\
\text { (Signif ikan) }\end{array}$ \\
\hline $\begin{array}{l}\text { Mode rasi Murni (Pure Moderator) } \\
\text { Moderasi Murni merupakan variabel yang } \\
\text { murni memoderasi hubungan antara variabel } \\
\text { bebas (independen) dan variabel terikat } \\
\text { (terikat) tanpa sekaligus menjadi variabel } \\
\text { bebas (independen) }\end{array}$ & $\begin{array}{c}\beta_{2}=0 \\
\text { (Tidak Signifikan) }\end{array}$ & $\begin{array}{c}\beta_{3} \neq 0 \\
\text { (Signifikan) }\end{array}$ \\
\hline
\end{tabular}

\section{Uji Sensitivitas}

Dalam penelitian ini, opini audit terbagi dalam dua jenis opini, yaitu opini audit nonmodifikasian dan opini audit modifikasian. Opini audit modifikasian, terbagi dalam tiga jenis opini, yaitu opini UEM, opini audit qualified dan opini audit disclaimer. Maka, penelitian ini juga melakukan analisis terhadap jenis opini audit modifikasian terhadap persistensi laba, dengan model sebagai berikut:

$$
\begin{aligned}
\text { EARNT }_{i t}=\alpha+ & \beta_{1} \text { EARN }_{i t-1}+\beta_{2} \text { UEM }_{i t-1}+\beta_{3} \text { QUALIFY }_{i t-1}+\square_{4} \text { DISCLAIM }_{i t-1}+\beta_{5} \text { EARN }_{i t-1} \\
& * \text { UEM }_{i t-1}+\beta_{6} \text { EARN }_{i t-1} * \text { DISCLAIM } \\
i t-1 & +\beta_{7} \text { EARN }_{i t-1} * \text { DISCLAIM }_{i t-1} \\
& +\beta_{8} \text { LEV }_{i t-1}+\beta_{9} \text { SIZE }_{i t-1}+\beta_{10} \text { LOSS }_{i t-1}+\beta_{11} \text { AUDITOR }_{i t-1}+\beta_{12} \text { ABS_ACC }_{i t-1} \\
& +\beta_{13} \text { DIV }_{i t-1}+\beta_{14} \text { INDUSTRY }+\varepsilon_{i t-1}
\end{aligned}
$$

Keterangan:
$E A R N_{i t}$
$E A R N_{i t-1}$
= Laba operasional dibagi dengan rata-rata jumlah aset tahun $\mathrm{t}$
$U E M_{i t-1}$
= Laba operasional dibagi dengan rata-rata jumlah aset tahun t-1
QUALIFY
$=1 \mathrm{jika}$ auditor memberikan opini modif ikasian di tahun $\mathrm{t}-1$ dan 0 lainnya
$D_{\text {ISCLAIM }}$
$=1 \mathrm{jika}$ auditor memberikan opini modifikasian di tahun $\mathrm{t}-1$ dan 0 lainnya
$E A R N_{i t-1} * U E M_{i t-1}$
$=1$ jika auditor memberikan opini modifikasian di tahun $\mathrm{t}-1$ dan 0 lainnya
= Interaksi antara opini audit unqualified with emphasis of matters (UEM) pada tahun t- 1 dan laba operasional dibagi dengan rata-rata jumlah aset pada tahun $\mathrm{t}-1$ 
$E A R N_{i t-1} * Q U A L I F Y_{i t-1}=$ Interaksi antara opini audit qualified pada tahun t-1 dan laba operasional dibagi dengan rata-rata jumlah aset pada tahun t-1

$E A R N_{i t-1} * D I S C L A I M_{i t-1}=$ Interaksi antara opini audit disclaimer pada tahun t-1 dan laba operasional dibagi dengan rata-rata jumlah aset pada tahun $\mathrm{t}-1$

$L E V_{i t-1} \quad=$ Total utang dibagi dengan total aset tahun $\mathrm{t}-1$

SIZEt $_{i t-1} \quad$ = logaritma natural dari total aset tahun $\mathrm{t}-1$

$\operatorname{LOSS}_{i t-1} \quad=1$ jika perusahaan mengalami kerugian pada tahun $\mathrm{t}-1$ dan 0 lainnya

AUDITOR $_{i t-1} \quad=1$ jika perusahaan diaudit oleh auditor Big 4 pada tahun $\mathrm{t}-1$ dan 0 la innya

$A B S \_A C C_{i t-1} \quad=$ Nilai absolut akrual, yang ditentukan dengan menghitung laba bersih dikurangi arus kas pada tahun $\mathrm{t}-1$, yang dihitung dengan rata-rata total aset

$D I V_{i t-1}$

Fixed effect pada tahun t-1

$=1$ jika perusahaan membayar dividen pada tahun $\mathrm{t}-1$ dan 0 lainnya

$=$ indikator industri dan tahun $\mathrm{t}-1$

\section{Hasil dan Diskusi}

\section{Statistik Deskriptif}

Tabel 4. Statistik Deskriptif Opini Audit Unqualified

\begin{tabular}{|c|c|c|c|c|c|}
\hline Variable & $\mathbf{N}$ & Min & Max & Mean & Std.Dev. \\
\hline $\mathrm{EARN}_{\mathrm{it}}$ & 1091 & $-1,744$ & 0,752 & 0,077 & 0,129 \\
\hline $\mathrm{EARN}_{\mathrm{it}-1}$ & 1091 & $-1,744$ & 0,658 & 0,086 & 0,125 \\
\hline $\mathrm{LEV}_{\mathrm{it}-1}$ & 1091 & 0 & 7,893 & 0,235 & 0,308 \\
\hline SIZE $_{\mathrm{it}-1}$ & 1091 & 0 & 19,383 & 14,446 & 1,801 \\
\hline $\operatorname{LOSS}_{\mathrm{it}-1}$ & 1091 & 0 & 1 & 0,165 & 0,371 \\
\hline AUDITOR $_{\mathrm{it}-1}$ & 1091 & 0 & 1 & 0,434 & 0,496 \\
\hline ABS_ACC ${ }_{i t-1}$ & 1091 & 0 & 1,653 & 0,077 & 0,103 \\
\hline DIV $_{\text {it-1 }}$ & 1091 & 0 & 1 & 0,511 & 0,500 \\
\hline
\end{tabular}

(Sumber: Data diolah)

Berdasarkan kedua tabel statistik deskriptif, diketahui bahwa terdapat 1.091 observasi merupakan opini audit unqualified dan 925 observasi merupakan opini audit modifikasian. Pada sampel opini audit unqualified, variabel laba tahun berjalan $\left(\mathrm{EARN}_{\mathrm{it}}\right)$ memiliki nilai maksimum sebesar 0,7521906 dan nilai minimum sebesar -1,744173. Sedangkan pada sampel opini audit modifikasian, variabel $\mathrm{EARN}_{\mathrm{it}}$ memiliki nilai maksimum sebesar 1,063192 nilai minimum sebesar 0,6786524 nilai rata-rata $\mathrm{EARN}_{\mathrm{it}}$ yang didapatkan adalah 0,066331 serta standar deviasi sebesar $0,1268136$. 
Tabel 5. Statistik Deskriptif Opini Audit Modifikasian

\begin{tabular}{lrrrrr}
\hline \multicolumn{1}{c}{ Variable } & N & \multicolumn{1}{c}{ Min } & \multicolumn{1}{c}{ Max } & Mean & Std.Dev. \\
\hline EARN $_{\text {it }}$ & 925 & $-0,7687$ & 1,0632 & 0,0663 & 0,1268 \\
EARN $_{\text {t-1 }}$ & 925 & $-0,7687$ & 1,0632 & 0,0674 & 0,1332 \\
LEV $_{\text {it-1 }}$ & 925 & 0 & 14,5395 & 0,3974 & 0,7327 \\
SIZE $_{\text {it-1 }}$ & 925 & 0 & 19,021 & 14,453 & 1,9867 \\
LOSS $_{\text {it-1 }}$ & 925 & 0 & 1 & 0,2746 & 0,4466 \\
AUDITOR $_{\text {it-1 }}$ & 925 & 0 & 1 & 0,3189 & 0,4663 \\
ABS_ACC $_{\text {it-1 }}$ & 925 & 0 & 2,5278 & 0,0940 & 0,1589 \\
DIV $_{\text {it-1 }}$ & 925 & 0 & 1 & 0,4259 & 0,4948 \\
\hline
\end{tabular}

(Sumber: Data diolah)

Variabel laba tahun sebelumnya $\left(\mathrm{EARN}_{\mathrm{it}-1}\right)$ pada sampel opini audit unqualified memiliki nilai maksimum sebesar 0,6575954 dan nilai minimum sebesar $-1,744173$ Nilai rata-rata yang didapatkan sebesar 0,0860614 dengan standar deviasi sebesar 0,1246404. Sedangkan pada sampel opini audit modifikasian, variabel $\mathrm{EARN}_{\mathrm{it}-1}$ memiliki nilai maksimum dan nilai minimum yang sama dengan variabel $\mathrm{EARN}_{\mathrm{t}}$ pada sampel opini audit modifikasian. Namun terdapat perbedaan nilai ratarata, yaitu 0,0673916 dan nilai standar deviasi yaitu 0,1332216 .

\section{Uji Ketepatan Model}

Setelah melakukan tiga tes dalam uji ketepatan model yaitu Chow Test, Lagrange Multiplier Test, dan Hausman Test maka didapatkan hasil uji model regresi yang baik untuk penelitian ini adalah Fixed Effect, namun dikarenakan penelitian menggunakan lima variabel dummy yang berdampak pada penelitian tidak dapat menggunakan uji model regresi Fixed Effect. Sehingga, uji model regresi yang tepat untuk penelitian berdasarkan hasil Lagrange Multiplier Test adalah Pooled Least Square.

\section{Uji Asumsi Klasik}

Dalam uji asumsi klasik, terdapat empat jenis uji yang harus dipenuhi yaitu uji normalitas, uji multikolinearitas, uji heteroskedastisitas, dan uji autokorelasi. Pada uji normalitas, terdapat lima variabel yaitu laba tahun lalu $\left(E A R N_{i t-1}\right)$, laba tahun berjalan $\left(\mathrm{EARN}_{\mathrm{it}}\right)$, leverage $\left(\mathrm{LEV}_{\mathrm{it}-1}\right)$, ukuran Perusahaan $\left(\mathrm{SIZE}_{\mathrm{it}-1}\right)$, dan absolut Akrual $\left(\mathrm{ABS} \_\mathrm{ACC}_{\mathrm{it}-1}\right)$ yang nilai skewness dan kurtosisnya tidak 
saki

dalam kategori normal. Sehingga dilakukan treatment pada kelima variabel tersebut. Tidak terdapat multikolerasi pada penelitian, namun ditemukan masalah heteroskedastisitas dan autokorelasi pada penelitian.

\section{Uji Hipotesis}

Tabel 6. Hasil Uji Hipotesis Model Penelitian

\begin{tabular}{|c|c|c|c|}
\hline \multirow{2}{*}{ Variabel } & \multicolumn{3}{|c|}{ Regresi } \\
\hline & Coeff & $\mathrm{t}$ & Prob $>\mathrm{t}$ \\
\hline _cons & 0,0426 & 3,09 & $0,002 * * *$ \\
\hline $\mathrm{EA} \mathrm{RN}_{\mathrm{it}-1}$ & 0,8090 & 27,14 & $0,000 * * *$ \\
\hline OPINION $_{\mathrm{it}-1}$ & 0,0120 & 2,53 & $0,012 * *$ \\
\hline $\mathrm{EARN}_{\mathrm{it}-1} *$ OPINION & $0,0702^{-}$ & $-1,89$ & $0,06^{*}$ \\
\hline LEVLOG & 0,0025 & 2 & $0,046 * *$ \\
\hline SIZELN & $0,0033^{-}$ & $-2,78$ & $0,006^{* * *}$ \\
\hline LOSS & $0,0028^{-}$ & $-0,9$ & 0,368 \\
\hline AUDITOR & 0,0109 & 5,04 & $0,000 * * *$ \\
\hline ABS_ACC & 0,0041 & 0,65 & 0,519 \\
\hline DIV & 0,0123 & 7,22 & $0,000 * * *$ \\
\hline INDUSTRY1 & 0,0000 & & \\
\hline INDUSTRY2 & 0,0052 & 0,45 & 0,656 \\
\hline INDUSTRY3 & $0,0010^{-}$ & $-0,2$ & 0,842 \\
\hline INDUSTRY4 & 0,0008 & 0,17 & 0,861 \\
\hline INDUSTRY5 & 0,0222 & 4,91 & $0,000 * * *$ \\
\hline INDUSTRY6 & 0,0102 & 1,29 & 0,196 \\
\hline INDUSTRY7 & 0,0009 & $-0,09$ & 0,930 \\
\hline INDUSTRY8 & 0,0014 & $-0,23$ & 0,820 \\
\hline Prob $>$ F & & 0,0000 & \\
\hline R-squared & & 0,7061 & \\
\hline
\end{tabular}

(Sumber: Data diolah)

\section{H1: Pengaruh laba tahun sebelumnya terhadap laba tahun berjalan}

Berdasarkan hasil regresi di atas, dapat terlihat bahwa laba tahun sebelumnya $\left(\mathrm{EARN}_{\mathrm{it}-1}\right)$ memiliki koefisien 0,8090 dan P-value sebesar 0,0000. Hasil ini menemukan bahwa laba tahun sebelumnya berpengaruh terhadap laba tahun berjalan yang menunjukkan bahwa terdapat persistensi 
laba pada perusahaan terbuka di Indonesia tahun 2011-2017. Dengan demikian, hipotesis pertama dalam penelitian diterima.

Hasil ini konsisten dengan penelitian yang dilakukan oleh Dechow et al. (2010), Fanani (2010, Moghaddam et al. (2016), Penman dan Zhang (2001), Sloan (1996), dan Vichitsarawong dan Pornupatham (2015) yang menemukan bahwa laba tahun lalu dapat berpengaruh pada laba tahun berjalan yang digambarkan sebagai persistensi laba. Laba dapat dikatakan persisten jika laba tersebut berkualitas. Mengacu pada Statement of Financial Accounting No. 2, laba yang berkualitas adalah laba yang relevan atau memiliki nilai prediksi, dimana laba tahun lalu sebelumnya dapat menjadi dasar yang tepat dalam memprediksi laba tahun berjalan. Laba yang persisten adalah laba yang memiliki pola yang stabil dari tahun ke tahun dan bersifat kontinu.

\section{H2: Opini audit medmoderasi pengaruh laba tahun sebelumnya terhadap laba tahun berjalan}

Berdasarkan hasil regresi, dapat dilihat bahwa variabel interaksi antara opini audit dan laba tahun sebelumnya $\left(\mathrm{EARN}_{\mathrm{it}-1} * \mathrm{OPINION}_{\mathrm{it}-1}\right)$ memiliki koefisien $-0,0702$ dan P-value sebesar 0,06. Hasil ini menunjukkan bahwa opini audit dapat memoderasi persistensi laba perusahaan, yang ditunjukkan dengan pengaruh laba tahun sebelumnya dengan laba tahun berjalan. Dengan demikian hipotesis kedua penelitian ini diterima.

Nilai koefisien variabel interaksi pada model ini sesuai dengan ekspektasi yang diharapkan, yaitu koefisien negatif, sebagaimana opini audit modifikasian merefleksikan adanya masalah dalam perusahaan sehingga cenderung memberikan efek negatif terhadap persistensi laba. Nilai negatif ini mengindikasikan bahwa opini audit modifikasian memperlemah hubungan antara laba tahun sebelumnya dan laba tahun berjalan, atau dalam kata lain opini audit modifikasian memperlemah persistensi laba. Hal ini terjadi karena pada perusahaan yang mendapat opini modif ikasian ditemukan bukti seperti masalah keuangan, penyusunan laporan keuangan yang tidak sesuai standar akuntansi yang berlaku atau keterbatasan ruang lingkup sehingga membuat ketidakpastian perusahaan dalam menjaga kelangsungan usahanya. 
Jika laba tersebut tidak menunjukkan laba yang kontinu atau laba perusahaan tidak persisten, berarti menunjukkan kualitas laba perusahaan rendah yang mengindikasikan adanya penurunan kinerja operasional perusahaan, kerugian, maupun masalah lainnya sehingga akan mempengaruhi investor atau pun calon investor dalam pengambilan keputusan. Maka, opini audit dalam hal ini juga berperan mengatasi kemungkinan adanya assymetrical information ataupun perbedaan kepentingan antara investor sebagai pemilik perusahaan dan manajemen sebagai pengelola sumber daya ekonomi perusahaan, karena opini audit dapat menggambarkan keadaan perusahaan yang sebenarnya.

Berikut merupakan tahapan dalam melakukan analisis regresi moderasi:

Regresi pertama:

$$
\begin{aligned}
\text { EARNT }_{i t}=0,0446 & +0,7772 \text { EARN }_{i t-1}+0,0024 \text { LEV }_{i t-1}-0,0030 \text { SIZE }_{i t-1}-0,0014 \text { LOSS }_{i t-1} \\
& +0,0102 \text { AUDITOR }_{i t-1}+0,0088 \text { ABS_ACC }_{i t-1}+0,0118 \text { DIV }_{i t-1}+0,039 \text { INDUSTRY }_{2} \\
& -0,0027 \text { INDUSTRY }_{3}+0,0002 \text { INDUSTRY }_{4}+0,0212 \text { INDUSTRY }_{5}+0,0089 \text { INDUSTRY }_{6} \\
& -0,0005 \text { INDUSTRY }_{7}-0,0025 \text { INDUSTRY }_{8}
\end{aligned}
$$

Regresi kedua:

$$
\begin{aligned}
\text { EARNT }_{i t}=0,0422 & +0,7763 \text { EARN }_{i t-1}+0,0065 \text { OPINION }_{i t-1}+0,0023 \text { LEV }_{i t-1}-0,0031 \text { SIZE }_{i t-1} \\
& -0,0022 \text { LOSS }_{i t-1}+0,0111 \text { AUDITOR }_{i t-1}+0,0085 \text { ABS_ACC }_{t i-1}+0,0119 \text { DIV }_{i t-1} \\
& +0,0049 \text { INDUSTRY }_{2}-0,0012 \text { INDUSTRY }_{3}+0,0007 \text { INDUSTRY }_{4}+0,0230 \text { INDUSTRY }_{5} \\
& +0,0100 \text { INDUSTRY }_{6}-0,0008 \text { INDUSTRY }_{7}-0,0018 \text { INDUSTRY }_{8}
\end{aligned}
$$

Regresi ketiga:

$$
\begin{aligned}
& \text { EARNT }_{i t}=0,0426+0,8090 \text { EARN }_{i t-1}+0,0120 \text { OPINION }_{i t-1}-0,0702 \text { EARN }_{i t-1} \times \text { OPINION }_{i t-1} \\
& + \text { 0,0025 } \text { LEV }_{i t-1}-0,0033 \text { SIZE }_{i t-1}-0,0028 \text { LOSS }_{i t-1}+0,0109 \text { AUDITOR }_{i t-1} \\
& +0,0041 \text { ABS_ACC } C_{i t-1}+0,0123 \text { DIV }_{i t-1}+\text { 0,0052 INDUSTRY } 2-0,0010 \text { INDUSTRY }_{3} \\
& + \text { 0,0008 INDUSTRY } 4 \text { + 0,0222 INDUSTRY } \text { IN }_{5} \text { 0,0102 INDUSTRY } 6 \text {-0,0009 INDUSTRY } 7 \\
& -0,0014 \text { INDUSTRY }_{8}
\end{aligned}
$$

Berdasarkan Analisis Regresi Moderasi (Moderated Regression Analysis/MRA), variabel opini audit (OPINION $\mathrm{it}_{\mathrm{it}-1}$ ) digolongkan menjadi moderasi semu (quasi moderator), maka sebenarnya 
opini audit dalam hal ini memiliki peran ganda, yaitu sebagai faktor yang dapat memperkuat ataupun memperlemah pengaruh antara laba tahun sebelumnya dan laba tahun berjalan, namun juga sekaligus sebagai faktor yang dapat secara langsung mempengaruhi laba tahun berjalan.

Hasil ini sejalan dengan penelitian yang dilakukan Vichitsarawong dan Pornupatham (2015) yang menemukan bahwa opini audit berpengaruh terhadap persistensi laba. Dalam penelitiannya, ia yang membuktikan bahwa perusahaan yang mendapatkan opini audit modifikasian cenderung memiliki persistensi laba yang lebih rendah dibandingkan perusahaan yang mendapatkan opini audit unqualified. Keadaan sejalan dengan penelitian Dechow et al.(2010), Choi dan Wong (1992), Krissindiastuti dan Rasmini (2016) dan Haron et al.(2009), yang menyatakan bahwa perusahaan mendapatkan opini audit modifikasian karena memiliki masalah dalam perusahaannya yang dapat mempengaruhi kelangsungan usahanya. Selain itu hasil ini juga sesuai dengan penelitian Fanani (2010), yang menyatakan persistensi laba mencerminkan kinerja perusahaan yang tergambar dari laba perusahaan yang berasal dari aktivitas operasional perusahaan.

\section{Uji Sensitivitas}

Penelitian tambahan dilakukan guna mengetahui pengaruh jenis opini audit modifikasian terhadap persistensi laba. Opini audit modifikasian terbagi dalam opini UEM, opini audit qualified (QUALIFY) dan opini audit disclaimer (DISCLAIM) yang termasuk dalam uji sensitivitas.

Tabel 7. Hasil Uji Sensitivitas Model Penelitian

\begin{tabular}{|c|c|c|c|}
\hline \multirow{2}{*}{ Variabel } & \multicolumn{3}{|c|}{ Regresi } \\
\hline & Coeff & $\mathrm{t}$ & $P>t$ \\
\hline _cons & 0,0481 & 5,19 & $0,000 * * *$ \\
\hline $\mathrm{EARN}_{\mathrm{it}-1}$ & 0,8191 & 26,31 & $0,000 * * *$ \\
\hline $\mathrm{UEM}_{\mathrm{it}-1}$ & 0,0101 & 2,05 & $0,041 * *$ \\
\hline QUALIFY $_{\mathrm{it}-1}$ & $-0,0275$ & $-1,96$ & $0,051 *$ \\
\hline DISCLA IM $_{\mathrm{t}-1}$ & $-0,0334$ & $-2,7$ & $0,007 * * *$ \\
\hline $\mathrm{EARN}_{\mathrm{it}-1} * \mathrm{UEM}_{\mathrm{it}-1}$ & $-0,0325$ & $-0,98$ & 0,326 \\
\hline $\mathrm{EARN}_{\mathrm{it}-1} * \mathrm{QUALIFY} Y_{\mathrm{it}-1}$ & $-0,4075$ & $-2,86$ & $0,005^{* * *}$ \\
\hline EA RN $_{\mathrm{it}-1} *$ DISCLA IM $\mathrm{it}_{\mathrm{it}-1}$ & $-2,5900$ & $-4,61$ & $0,000 * * *$ \\
\hline $\mathrm{LEV}_{\mathrm{it}-1}$ & 0,0037 & 2,98 & $0,003 * * *$ \\
\hline $\mathrm{SIZE}_{\mathrm{it}-1}$ & $-0,0035$ & $-3,62$ & $0,000 * * *$ \\
\hline $\operatorname{LOSS}_{\mathrm{it}-1}$ & $-0,0016$ & $-0,64$ & 0,525 \\
\hline
\end{tabular}




\begin{tabular}{|l|rrr|} 
AUDITOR $_{\text {it-1 }}$ & 0,0100 & 4,27 & $0,000^{* * *}$ \\
ABS_ACC $_{\text {it-1 }}$ & 0,0048 & 0,51 & 0,611 \\
DIV $_{\text {it-1 }}$ & 0,0098 & 5,1 & $0,000^{* * *}$ \\
INDUSTRY1 & 0,0000 & & \\
INDUSTRY2 & 0,0033 & 0,28 & 0,782 \\
INDUSTRY3 & $-0,0024$ & $-0,46$ & 0,646 \\
INDUSTRY4 & $-0,0005$ & $-0,1$ & 0,924 \\
INDUSTRY5 & 0,0193 & 3,52 & $0,001^{* * *}$ \\
INDUSTRY6 & 0,0092 & 1,08 & 0,279 \\
INDUSTRY7 & $-0,0018$ & $-0,2$ & 0,843 \\
INDUSTRY8 & $-0,0020$ & $-0,27$ & 0,788 \\
Prob > F & & 0,0000 & \\
R-squared & & 0,7180 & \\
\hline
\end{tabular}

(Sumber: Data diolah)

EARN $_{\mathrm{it}-1} * \mathrm{QUALIFIED}_{\mathrm{it}-1}$ memiliki koefisien $-0,4075$ dan P-value sebesar 0,005 , sehingga opini audit qualified memoderasi hubungan antara laba tahun sebelumnya dan laba tahun berjalan. Hasil ini juga sesuai dengan ekspektasi penelitian yang mendapatkan nilai koefisien negatif. Sehingga dapat dikatakan bahwa opini audit qualified dapat memperlemah persistensi laba. Hasil ini sejalan dengan penelitian yang dilakukan Vichitsarawong dan Pornupatham (2015) yang juga menyatakan bahwa opini audit qualified dapat berpengaruh terhadap persistensi laba karena menurut Frost (1997), perusahaan yang mendapatkan opini audit qualified adalah perusahaan yang memiliki keadaan keuangan yang lemah dan berpengaruh terhadap penurunan profitabilitas perusahaan yang signifikan jika dibandingkan dengan perusahaan yang mendapatkan opini audit unqualified, sehingga berpengaruh terhadap persistensi laba perusahaan.

Jenis opini audit disclaimer terbukti memoderasi hubungan antara laba tahun sebelumnya dan laba tahun berjalan yang ditunjukkan dengan koefisien $-2,5900$ dan $\mathrm{P}$-value 0,0000 pada variabel EARN $_{\mathrm{it}-1}$ *DISCLAIM $_{\mathrm{it}-1}$. Keadaan tersebut sesuai dengan Ikatan Akuntansi Indonesia (SA 705) yang menyatakan auditor memberikan opini disclaimer jika auditor tidak memperoleh bukti audit yang cukup, yang dapat menjadi dasar dari pemberian opini. Padahal menurut Arens et al. (2012), audit dilakukan untuk mengevaluasi bukti informasi dalam laporan keuangan untuk dapat menentukan dan melaporkan informasi sesuai dengan kriteria atau asersi yang telah ditentukan yang mencakup 
keberadaan atau keterjadian (existence or occurrence), kelengkapan (completeness), hak dan kewajiban (rights and obligation), penilaian (valuation) dan penyajian dan pengungkapan (presentation and disclosure). Apabila auditor saja tidak memiliki bukti yang cukup untuk menentukan pendapat atas laporan keuangan berdasarkan asersi audit tersebut, maka hal ini dapat menjadi indikator bahwa kualitas laba perusahaan rendah.

Berikut merupakan tahapan dalam melakukan analisis regresi moderasi pada uji sensitivitas:

Regresi pertama:

$$
\begin{aligned}
\text { EARNT }_{i t}=0,04 & +0,7772 \text { EARN }_{i t-1}+0,0024 \text { LEV }_{i t-1}-0,0030 \text { SIZE }_{i t-1}-0,0014 \text { LOSS }_{i t-1} \\
& +0,0102 \text { AUDITOR }_{i t-1}+0,0088 \text { ABS_ACC }_{i t-1}+0,0118 \text { DIV }_{i t-1}+0,039 \text { INDUSTRY }_{2} \\
& -0,0027 \text { INDUSTRY }_{3}+0,0002 \text { INDUSTRY }_{4}+0,0212 \text { INDUSTRY }_{5}+0,0089 \text { INDUSTRY }_{6} \\
& -0,0005 \text { INDUSTRY }_{7}-0,0025 \text { INDUSTRY }_{8}
\end{aligned}
$$

Regresi kedua:

$$
\begin{aligned}
& E_{\text {ERNT }}=0,0429+0,7729 \text { EARN }_{i t-1}+0,0075 \text { UEM }_{i t-1}-0,0438 \text { QUALIFY }_{i t-1}+0,1217 \text { DISCLAIM }_{i t-1} \\
& +0,0027 L_{E V} V_{i t-1}-0,0031 \text { SIZE }_{i t-1}-0,0020 \text { LOSS }_{i t-1}+0,0111 \text { AUDITOR }_{i t-1} \\
& +0,0159 \text { ABS_ACC } i t-1+0,0110 D_{i t} V_{i t-1}+0,0030 \text { INDUSTRY }_{2}-0,0023 \text { INDUSTRY }_{3} \\
& + \text { 0,0011 INDUSTRY } 4+0,0212 \text { INDUSTRY }_{5}+0,0086 \text { INDUSTRY }_{6}-0,0021 \text { INDUSTRY }_{7} \\
& -0,0034 \text { INDUSTRY }_{8}
\end{aligned}
$$

Regresi ketiga:

$$
\begin{aligned}
\text { EARNT }_{i t}=0,0481 & +0,8191 \text { EARN }_{i t-1}+0,0101 \text { UEM }_{i t-1}-0,0275 \text { QUALIFY }_{i t-1}-0,0334 \text { DISCLAIM }_{i t-1} \\
& -0,0325 \text { EARN }_{i t-1} * \text { UEM }_{i t-1}-0,4075 \text { EARN }_{i t-1} * \text { QUALIFY }_{i t-1}-2,5900 \text { EARN }_{i t-1} \\
& * \text { DISCLAIM }_{i t-1}+0,0037 \text { LEV }_{i t-1}-0,0035 \text { SIZE }_{i t-1}-0,0016 \text { LOSS }_{i t-1} \\
& +0,0100 \text { AUDITOR }_{i t-1}+0,0048 \text { ABS_ACC }_{i t-1}+0,0098 \text { DIV }_{i t-1}+0,0033 \text { INDUSTRY }_{2} \\
& -0,0024 \text { INDUSTRY }_{3}+0,0005 \text { INDUSTRY }_{4}+0,0193 \text { INDUSTRY }_{5}+0,0092 \text { INDUSTRY }_{6} \\
& -0,0018 \text { INDUSTRY }_{7}-0,0020 \text { INDUSTRY }_{8}
\end{aligned}
$$


Sama seperti hasil Analisis Regresi Moderasi (Moderated Regression Analysis/MRA) pada model utama, pada model tambahan ini, opini audit qualified dan disclaimer digolongkan sebagai moderasi semu (quasi moderator). Maka sama seperti dalam model utama, opini audit dalam hal ini memiliki peran ganda, yaitu sebagai faktor yang dapat memperkuat ataupun memperlemah pengaruh antara laba tahun sebelumnya dan laba tahun berjalan, namun juga sekaligus sebagai faktor yang dapat secara langsung mempengaruhi laba tahun berjalan.

\section{Kesimpulan, Implikasi, dan Keterbatasan}

Penelitian dilakukan untuk menguji adanya persistensi laba yang diukur menggunakan pengaruh antara laba tahun sebelumnya dan laba tahun berjalan, serta untuk menguji apakah opini audit memoderasi pengaruh laba tahun sebelumnya dan laba tahun berjalan pada perusahaan yang terdaftar di Bursa Efek Indonesia dari tahun 2011-2017. Berdasarkan analisis, penelitian ini berhasil membuktikan adanya pengaruh signifikan antara laba tahun sebelumnya dengan laba tahun berjalan. Hasil penelitian ini sejalan dengan penelitian terdahulu yang dilakukan Sloan (1996), Penman dan Zhang (2001), Dechow et. al. (2010), Fanani (2010), Vichitsarawong dan Pornupatham (2015) dan Moghaddam et. al. (2016) yang menje laskan bahwa laba tahun sebelumnya merupakan cerminan laba tahun berjalan, dan laba tahun lalu dapat menjadi indikator yang tepat untuk memperkirakan besaran laba tahun berjalan.

Selain itu, penelitian ini juga membuktikan bahwa opini audit dapat memoderasi pengaruh laba tahun sebelumnya terhadap laba tahun berjalan, konsisten dengan penelitian terdahulu oleh Vichitsarawong dan Pornupatham (2015). Pengujian tersebut dilakukan dengan menggunakan variabel opini audit $\left(\mathrm{OPINION}_{\mathrm{it}-1}\right)$, yang merupakan opini audit modifikasian, sebagai variabel moderasi yang diinteraksikan dengan laba tahun sebelumnya $\left(\mathrm{EARN}_{\mathrm{it}-1}\right)$ Hasil uji menunjukkan bahwa terdapat pengaruh signifikan antara variabel interaksi $\left(\mathrm{EARN}_{\mathrm{it}-1} * \mathrm{OPINION}_{\mathrm{it}-1}\right)$ dengan laba tahun berja lan $\left(\mathrm{EARN}_{\mathrm{it}}\right)$ yang merupakan variabel dependen. 
Koefisien pada variabel interaksi $\left(\mathrm{EARN}_{\mathrm{it}-1} * \mathrm{OPINION}_{\mathrm{it}-1}\right)$ menunjukkan nilai negatif, maka variabel moderasi opini audit berarti memiliki sifat memperlemah. Dengan demikian, opini audit modifikasian dapat memperlemah persistensi laba. Namun berdasarkan hasil Analisis Regresi Moderasi (Moderated Regression Analysis/MRA), hasil interaksi opini audit dengan laba tahun sebelumnya menunjukkan bahwa variabel opini audit $\left(\mathrm{OPINION}_{\mathrm{it}-1}\right)$ digolongkan sebagai moderasi semu (quasi moderasi). Dengan demikian, opini audit modifikasian (OPINION $\left.{ }_{\mathrm{it}-1}\right)$ sebenarnya belum bisa dikatakan memperlemah atau memoderasi secara murni persistensi laba, mengingat peran ganda yang dimiliki opini audit, yaitu sebagai variabel moderasi sekaligus sebagai variabel independen yang memiliki pengaruh langsung terhadap laba tahun berja lan.

Dalam uji sensitivitas, penelitian ini juga berhasil membuktikan bahwa opini audit qualified dan opini audit disclaimerdapat memoderasi persistensi laba, yang juga konsisten dengan hasil penelitian yang dilakukan Vicitsarawong dan Pornupatham (2015). Kedua jenis opini audit tergolong ke dalam moderasi semu (quasi moderator), yang berarti variabel opini audit qualifieddan opini audit disclaimer memiliki fungsi ganda yang berarti bukan hanya sebagai variabel moderasi, namun juga sebagai variabel independen yang memiliki pengaruh langsung terhadap laba tahun berjalan. Sedangkan hasil analisis regresi moderasi pada jenis opini UEM menunjukkan hasil yang tidak signifikan, yaitu opini audit UEM tidak dapat memoderasi persistensi laba. Berdasarkan hasil analis is regresi moderasi, opini audit UEM tergolong ke dalam prediktor moderasi, yang berarti opini audit tersebut berfungsi sebagai variabel independen.

Penelitian ini memiliki beberapa keterbatasan. Keterbatasan penelitian yang pertama adalah sampel perusahaan yang mendapatkan opini qualifieddan disclaimer hanya 1,39\% dan 0,15\% dari total keseluruhan sampel sehingga dianggap kurang representatif. Penelitian selanjutnya diharapkan dapat mendapatkan sampel opini qualified dan disclaimer lebih banyak, sehingga data dapat lebih representatif. Penelitian ini hanya menggunakan satu proksi untuk mengukur persistensi laba yaitu dengan laba operasional dibagi rata-rata total aset. Penelitian selanjutnya diharapkan dapat menggunakan proksi lain, yaitu akrual dan arus kas tahun sebelumnya, yang pada penelitian ini hanya 
dijadikan sebagai variabel kontrol yang menggambarkan kualitas laba. Selain itu, penelitian selanjutnya diharapkan juga dapat menambahkan audit tenure sebagai variabel kontrol.

Penelitian juga memberikan implikasi sebagai referensi mengenai pengaruh opini audit terhadap persistensi laba dalam pengambilan keputusan investasi oleh investor atau calon investor dan memberikan pemahaman baru terkait pentingnya peran opini audit dalam memberikan gambaran keadaan perusahaan yang sebenarnya. Selain itu, penelitian juga memberikan implikasi terhadap pihak akademisi agar dapat dijadikan referensi tambahan dalam melakukan penelitian selanjutnya mengenai opini audit dan persistensi laba.

\section{Daftar Pustaka}

Arens, A.A., Elder, R. J., Beasley, M. S., Hogan, C. E., (2012). Auditing and Assurance Service. England: Pearson Education Limited

Belkaoui, A. R. (1993). Accounting Theory. New York: Harcourt Brace Jovanovich.

Bellovary, J., Akers, M. \& Diacomino, D. (2005). Earnings Quality : Its Time to Measure and Report. The CPA Journal, 72(11), 32-37

Budiyasa, A.A.P.M. \& Sisdyani, E. A. (2015). Analis is laba dan Arus Kas Operasi Sebagai Prediktor Arus Kas Masa Depan. Jurnal Akuntansi Universitas Udayana, 13(1). 344

Choi, J. \& Wong, T.J. 1992. Auditors' governance functions and legal environments: An international investigation. Contemporary Accounting Research, 24(1).13-46. https://doi.org/10.1506/X4781075-4PW5-1501

Cohen, D.A. (2003). Quality of Financial Reporting Choice: Determinants and Economic Consequences. Working Paper, Northwestern University Collins

Dechow, P. M., Ge, W. \& Schrand, C. (2010). Understanding Earnings Quality: A Review of the Proxies, the ir Determinants and their Consequences. Journal of Accounting and Economics, 344-401. https://doi.org/10.1016/j. jacceco.2010.09.001

Fadjar, A. \& Firdaus, H. F. (2009). Pertimbangan Auditor dalam Mengumpulkan Bukti Audit terhadap Pendapat Wajar Tanpa Pengecualian. Jurnal Bisnis Manajeman dan Ekonomi, 1, 7986

Fanani (2010). Analis is Faktor-faktor Penentu Persistensi Laba, Jurnal Akuntansi dan Keuangan Indonesia, 7(1), 109-123 http://dx.doi.org/10.21002/jaki.2010.06

Frost, C.A. (1997). Disclosure Policy Choices of UK Firms Receiving Modified Audit Reports. Journal of Accounting and Economics, 23, 163-187

Gujarati, D.N. (2003). Basic Econometrics. New York: McGraw Hill Book Co.

Haron, Hartadi, Ansari \& Ismail (2009). Factors Influencing Auditors' Going Concern Opinion. Asian Academy of Management Journal, 14(1), 1-19

Hariyati, T. (2014). Pengaruh Karakteristik Perusahaan Terhadap Tindakan Perataan Laba. Jurnal Ilmu \& Riset Akuntansi, 3(9), 1-25

Herusetya, A. (2012). Analisis Kualitas Audit Terhadap Manajemen Laba Akuntansi: Studi Pendekatan Composite Measure Versus Conventional Measure. Jurnal Akuntansi dan Keuangan Indonesia, 9(2), 8-20. http://dx.doi.org/10.21002/jaki.2012.08

Ikatan Akuntansi Indonesia. 2015. Pernyataan Standar Akuntasi Keuangan. 


\section{saki}

Imroatussolihah, E. (2013). Pengaruh Risiko, Leverage, Peluang Pertumbuhan, Persistensi Laba dan Kualitas Tanggung Jawab Sosial Perusahaan terhadap Earning Response Coefficient pada Perusahaan High Profile. Jurnal Ilmiah Manajemen, 1(1), 75-87

Jensen, M. C. \& Meckling, W. H. (1976), Theory of the Firm: Managerial Behavior, Agency Cost and Ownership Structure. Journal of Financial Economics 3, 305-360. https://doi. org/10.1016/0304-405X(76)90026-X

Julianto, E. (2010). Dasar Pertimbangan dan Proses Perumusan Opini dalam Pemeriksaan atas Laporan Keuangan Daerah.

Krissindiastuti, M. \& Rasmini, N. K. (2016). Faktor-faktor yang Mempengaruhi Opini Audit Going Concern. E-Jurnal Akuntansi Universitas Udayana, 14(1), 451-481

Moghaddam, Monavar, Mostafaei, Ghased \& Kakhi (2016). Investigating the Relationship between Audit Opinion and Earnings Persistence of Listed Firms in Tehran Stock Exchange. Speciality Journal of Accounting and Economics, 2(1), 71-76

Munawir, S. (2007), Analisis Laporan Keuangan. Yogyakarta: Liberty

Osesoga, M.S. \& Ardianto, J. (2011). Pengaruh Opini Audit terhadap Earnings Responses Coefficient (Studi Empiris Pada Perusahaan yang Termasuk dalam Indeks Kompas 100 Tahun). Ultima Accounting. 3(2), 64-83

Penman, Zhang. (2002), Accounting Concervatism, the Quality of Earnings, and Stock Returns, Accounting Journal, 77(2), 237-264. https://doi.org/10.2308/accr.2002.77.2.237

Rudyawan, A. P. \& Badera, I. D. N. (2009). Opini Audit Going Concern: Kajian Berdasarkan Model Prediksi Kebangkrutan, Pertumbuhan Perusahaan, Leverage dan Reputasi Auditor. Jurnal Ilmiah Akuntansi dan Bisnis, 4(2), 2303-1018.

Schipper, K. \& Vincent L. (2003). Earnings Quality. Accounting Horizons, 17, 97-110

Sharma, Durand, Gur-Arie (1981). Identification and Analysis of Moderator Variables. Journal of Marketing Research, 18 (3), 291-300

Sloan, R. G. (1996). Do Stock Prices Fully Reflect Information in Accruals and Cash Flows about Future Earnings?. The Accounting Review, 71(3), 289-315

Sujana, I. M., Yasa, G. W., \& Badera I. D. N. (2017). Pengaruh Komite Audit dan Kepemilikan Institusional pada Persistensi Laba Perusahaan Manufaktur. E-Jurnal Ekonomi dan Bisnis Universitas Udayana, 6(12), 4311-4338

Subramanyam, K. R. \& Wild, J. J. (1996). Financial Statement Analysis. New York: McGraw-Hill Irwin

Sugiono (2004). Konsep, Identifikasi, Alat Analisis dan Masalah Penggunaan Variabel Moderator. Jurnal Studi Manajemen \& Organisasi, 1 (2), 61-70

Surifah. (2010). Kualitas laba dan Pengukurannya. Jurnal Ekonomi Manajemen \& Akuntansi, 8(2). 32-33.

Tobing, R., \& Nirwana. (2004). Kamus Istilah Akuntansi. Jakarta: Atalya Rileni Sucedo

Vichitsarawong, T. \& Pornupatham, S. (2015), Do Audit Opinions Reflect Earnings Persistence?. Managerial Auditing Journal, 30(3), 244-276. https //doi.org/10.1108/MAJ-12-2013-0973

Yocelyn, A. \& Christiawan, Y. J. (2012). Analis is Pengaruh Perubahan Arus Kas dan Laba Akuntansi Terhadap Return Saham pada Perusahaan Berkapitalisasi Besar. Jurnal Akuntansi dan Keuangan, 14(2), 81-90

Zedeck, S. (1971). Problems With The Use Of "Moderator" Variables. Psychollogical Bulletin, 76(4), 295-310. https://doi.org/10.1037/h0031543 